\title{
Popularization of Tomato Hybrid (Arka Rakshak) for Yield and Economic Analysis in Kalyan Karnatka Region
}

\author{
S.M. Kale ${ }^{1 *}$, Barikar Umesh ${ }^{2}$ and C. Mahesh ${ }^{3}$ \\ ${ }^{1}$ Horticulture, ${ }^{2}$ Soil \& water engineering, ${ }^{3}$ Animal Science, ICAR-Krishi Vigyan Kendra, \\ Kawadimatti, Shorapur (Tq), Yadgir (Dist)-585224, India \\ *Corresponding author
}

A B S T R A C T

\begin{tabular}{l} 
K e y w o r d s \\
Front line \\
demonstration, \\
Extension gap, \\
Technology index, \\
Tomato \\
\hline Article Info \\
\hline $\begin{array}{l}\text { Accepted: } \\
18 \text { May } 2020 \\
\text { Available Online: } \\
\text { 10 June } 2020\end{array}$ \\
\hline
\end{tabular}

A front line demonstration was conducted by ICAR- Krishi Vigyan Kendra Yadagir, (Karnataka) during Rabi season of 2018 and 2019 to study the varietal demonstration in Tomato for yield and economic analysis at the farmer's field of three Talukas viz., Shorapur, Shahpur and Yadagir district. During these two years of study, an area of 4 ha was covered under FLDs with active participation of 20 farmers. The average fruit yield was $315 \mathrm{q} / \mathrm{ha}$ during 2018-19 and 570 during 2019-20 with the increase in percentage of yield ranged between 31.4 to 24.4 during two years of the study. The extension gap ranging 99 to $140 \mathrm{q} / \mathrm{ha}$ and technology gap ranging between 365 and $139 \mathrm{q} / \mathrm{ha}$. Reduction in technology index from 53.67 per cent during 2018-19 to 20.44 per cent during 2019-20 exhibited the feasibility of the demonstrated technology in this region.

\section{Introduction}

Tomato (Lycopersicon esculentum Mill.) belonging to family solanaceae is one of the most important vegetable, widely grown throughout the world for supplying in the fresh market as well as for processing. Tomato is the second most consumed vegetable after potato (FAOSTAT, 2007). Tomato considered as a 'protective food' is being extensively grown as annual vegetable crop all over the world. It is an important source of vitamin A, vitamin C and lycopene that are potent antioxidants. It is grown round the year. In India, it is grown in an area of 8.94 lakh hectares with annual production of 196.96 lakh tones and average productivity 28 t/ha (Anonymous, 2018). In Karnataka is one of the leading producers with 64250 hectare area during 2018-19.

Tomato requires warm climate as well as cool climate, but it is a warm season crop. Tomato plant does not tolerate frost and high 
humidity. Pigmentation, fruit set, fruit color are affected by light intensity. Tomato plants thrive well in temperature $10^{\circ} \mathrm{C}$ to $30^{\circ} \mathrm{C}$ with optimum range of temperature is $21-24^{0} \mathrm{C}$. Well drained sandy loam soil with high level of organic contents is best suitable for tomato cultivation. Soils with high acidity are not suitable for tomato cultivation. Yadgir (KA) district comes under in two zones like North Eastern transition and North Eastern dry zone. is bestowed with the agro-climatic condition, which is very suitable for tomato cultivation. Lack of proper knowledge about the cultivars best suited to the agro-climatic condition, the potential of tomato is not fully exploited. Before recommendation of any cultivars suitable for the region, it is pertinent to evaluate cultivars giving emphasis on the aspect of genotypic suitability and yield. Varietal performance of tomato varies from place to place due to the varied climatic conditions. Considering all the above mentioned facts, a pertinent need was felt to undertake an experiment on genotype performance of Arka Rakshak cultivar of tomato under Kalyan Karnataka region so as to ascertain and recommend, the cultivars best suited for the agro-climatic condition of the Yadagir district. The zones indicate the predominance of rain dependent dry land agricultural area. The normal rainfall of the district is $636 \mathrm{mms}$.

The KVK-Yadgir organizes front line demonstrations (FLDs) which aim at demonstrating newly released tomato variety Arka Rakshak on farmer's fields. KVKs are playing strategic role in technology backstopping, knowledge management and advisory to the different stakeholders like farmers, farm women, rural youths and extension personnel. Front line demonstration can be enhanced by adopting cost and input efficient technologies, and the bridge in yield gap may be level up to certain extent. To show case the high yielding new varieties, to convince them to about the potential of improved production technologies to enhance yield of tomato. Frontline demonstrations were undertaken in a systematic manner on farmer's field to show the worth of improved practices and convince the farmers to adopt in their farming system.

\section{Materials and Methods}

The study was carried out by ICAR- Krishi Vigyan Kendra Yadagir, (Karnataka) during Rabi season of 2018 and 2019 at the farmer's field of three Talukas viz., Shorapur, Shahpur and Yadagir district. During these two years of study, an area of 4 ha was covered under FLDs with active participation of 20 farmers. Before conducting FLDs, lists of farmers were prepared from group meetings and specific skill training was imparted to the selected farmers regarding different aspects of cultivation. The field was prepared by deep ploughing and harrowing. The seeds were sown in well prepared raised bed during September. In check (control) plot; farmers were applied in their regular practices (local variety). The crop was harvested at maturity stage. The difference between the demonstration package and existing farmer's practices are mentioned in Table 1.

The extension tools such as extension gap, technology gap, and technology index were calculated as suggested by (Suthar et al., 2016) to study impact of front-line demonstrations among selected farmers in paddy crop.

Technology gap = Potential yield Demonstrated yield

Extension gap $=$ Demonstrated yield - Yield under existing practice

Technology index $=\frac{\text { Potential yield }- \text { Demonstrated yield }}{\text { Potential yield }} \times 100$ 


\section{Results and Discussion}

A perusal of data (Table 2) indicates that the yield of tomato increased successively over the years in demonstration plots. The average fruit yield was 315q/ha during 2018-19 and 570 during 2019-20 with the increase in percentage of yield ranged between 31.4 and 24.4 during two years of the study.

The result revealed the positive effects of FLD over the existing practices as it enhanced the yield of tomato in Yadgir district of Karnataka.
The extension gap ranging between 99 to140 $\mathrm{q} / \mathrm{ha}$ during the period of study emphasizes the need to educate the farmers through various means for the adoption of improved agricultural production to reverse the trend of wide extension gap. The trend of technology gap ranging between 365 and $139 \mathrm{q} / \mathrm{ha}$ reflected the farmer's cooperation in carrying out such demonstration with encouraging results in subsequent years. The technology gap observed may be attributed to the dissimilarity in soil fertility status and weather condition. Similar findings were also recorded by Singh et al., (2016) and Chapke (2012).

Table.1 Level of use and gap in adoption of tomato technologies in study area

\begin{tabular}{|c|c|c|c|}
\hline Crop operations & Improved package of practices & Farmers practices & Gap \\
\hline Variety & Arka Rakshak & Himsona & Full gap \\
\hline Soil testing & Have been done in all locations & Not in practice & Full gap \\
\hline Seed rate & $100 \mathrm{gm} / \mathrm{ha}$ & $200 \mathrm{gm} / \mathrm{ha}$ & Full gap \\
\hline Seed treatment & $\begin{array}{l}\text { Seed was treated with Captan @ 2- } \\
3 \mathrm{~g} / \mathrm{kg} \text { seeds or carbendazim @ } 1 \mathrm{~g} \\
/ \mathrm{kg} \text { seed and with Imidacloprid @ } \\
2.0 \mathrm{~g} / \mathrm{Kg} \text { seed }\end{array}$ & Not in practice & Full gap \\
\hline $\begin{array}{l}\text { Transplanting } \\
\text { method }\end{array}$ & $\begin{array}{l}\text { Transplanting in ridges Row to } \\
\text { Row } 90 \mathrm{~cm} \mathrm{\&} \\
\text { Plant to Plant } 75 \mathrm{~cm}\end{array}$ & $\begin{array}{l}\text { Flat bed transplanting } \\
\text { Row to Row } 60 \mathrm{~cm} \mathrm{\&} \\
\text { Plant to Plant } 30 \mathrm{~cm}\end{array}$ & $\begin{array}{l}\text { Partial } \\
\text { gap }\end{array}$ \\
\hline $\begin{array}{l}\text { Transplanting } \\
\text { time }\end{array}$ & September & June & $\begin{array}{l}\text { Partial } \\
\text { gap }\end{array}$ \\
\hline Fertilizer dose & POP 250:250:250kg (N:P:K) & Only $\mathrm{N}$ and $\mathrm{P}$ & $\begin{array}{l}\text { Partial } \\
\text { gap }\end{array}$ \\
\hline Micronutrient & Arka Vegetable special (4 times) & $\begin{array}{l}\text { Not aware of } \\
\text { micronutrients }\end{array}$ & Full gap \\
\hline $\begin{array}{l}\text { Weed } \\
\text { management }\end{array}$ & Hand weeding 3-4 times & Hand weeding (2 times) & $\begin{array}{l}\text { Partial } \\
\text { gap }\end{array}$ \\
\hline Plant protection & $\begin{array}{l}\text { Integrated pest and disease } \\
\text { management }\end{array}$ & Only chemical spray & $\begin{array}{l}\text { Partial } \\
\text { gap }\end{array}$ \\
\hline $\begin{array}{l}\text { Use of yellow } \\
\text { sticky card }\end{array}$ & Installed 8-10 for acre & Not in practice & Full gap \\
\hline $\begin{array}{l}\text { Marigold as } \\
\text { intercrop }\end{array}$ & $\begin{array}{l}\text { Thirty rows of tomato with one } \\
\text { row of marigold }\end{array}$ & Not in practice & Full gap \\
\hline
\end{tabular}


Table.2 Yield of Tomato, technology gap, extension gap and technology index as influenced by improved practices

\begin{tabular}{|c|c|c|c|c|c|c|c|}
\hline \multirow[t]{2}{*}{ Year } & \multicolumn{3}{|c|}{ Fruit yield (t/ha) } & \multirow{2}{*}{$\begin{array}{c}\% \\
\text { Increase }\end{array}$} & \multirow{2}{*}{$\begin{array}{c}\text { Technology } \\
\text { gap (q/ha) }\end{array}$} & \multirow{2}{*}{$\begin{array}{l}\text { Extension } \\
\text { gap (q/ha) }\end{array}$} & \multirow{2}{*}{$\begin{array}{l}\text { Technology } \\
\text { index }(\%)\end{array}$} \\
\hline & $\begin{array}{l}\text { Demo } \\
\text { (q/ha) }\end{array}$ & $\begin{array}{l}\text { Check } \\
\text { (q/ha) }\end{array}$ & $\begin{array}{l}\text { Potential } \\
\text { (q/ha) }\end{array}$ & & & & \\
\hline 2018-19 & 315 & 216 & 680 & 45.83 & 365 & 99 & 53.67 \\
\hline 2019-20 & 570 & 431 & 680 & 32.25 & 139 & 140 & 20.44 \\
\hline
\end{tabular}

Table.3 Economic analysis of tomato demonstration

\begin{tabular}{|c|c|c|c|c|}
\hline Year & $\begin{array}{c}\text { Cost of } \\
\text { Cultivation } \\
\text { (Rs/ha) }\end{array}$ & $\begin{array}{c}\text { Gross Return } \\
\text { (Rs/ha) }\end{array}$ & $\begin{array}{c}\text { Net Return } \\
\text { (Rs/ha) }\end{array}$ & $\begin{array}{c}\text { Benefit Cost ratio } \\
\text { B:C Ratio }\end{array}$ \\
\hline $\mathbf{2 0 1 8 - 1 9}$ & 40280 & 107500 & 67220 & 1.70 \\
\hline $\mathbf{2 0 1 9}-20$ & 122140 & 524145 & 402005 & 4.57 \\
\hline
\end{tabular}

The technology index showed the feasibility of the evolved technology at the farmer's field. The lower the value of technology index, the more is the feasibility of the technology. As such, the reduction in technology index from 53.67 per cent during 2018-19 to 20.44 per cent during 2019-20 exhibited the feasibility of the demonstrated technology in this region. Similar observations were found by Katare et al., (2011), Keshavareddy et al., (2018) and Dayanand (2012) in mustard.

\section{Benefit- Cost (B: C) ratio}

In order to ascertain the economic feasibility of the demonstration technologies over and above the control, some economic indicators like cost of cultivation, net return and $\mathrm{B}$ : $\mathrm{C}$ ratio was worked out. The economic viability of improved demonstrated technology over farmers practice was calculated depending on prevailing price of inputs and output cost and represented in term of $\mathrm{B}$ : $\mathrm{C}$ ratio (Table 3 ). It was found that the cost of production of tomato under demonstration varied from Rs 40,280 to $1,22,140$ /ha. The additional cost increased in the demonstration was mainly due to more cost involved in balanced fertilizer, procurement of improved hybrid and IPM practices. The data revealed that the net return from the demonstration were substantially higher than control plots similar results are in corroboration with the findings of Mokidue et al., (2011) and Keshavareddy et al., (2018).

$\mathrm{B}$ : $\mathrm{C}$ ratio was recorded to be higher under demonstration against control during both the years of study. Scientific method of tomato cultivation can reduce the technology gap to a considerable extent, thus leading to increased productivity of tomato in the district which in turn will improve the economic condition of the growers. Moreover, extension agencies in the district need to provide proper technical support to the farmers through different educational and extension methods to reduce the extension gap for better tomato production in the district.

In conclusion, the study reported that of knowledge among tomato growers about disease resistant and high yielding tomato hybrid. The high productivity in demonstration plots over farmers practice 
(check) created awareness among the tomato growers and motivated other farmers to adopt appropriate improved production and protection technologies in tomato cultivation.

\section{Acknowledgement}

The authors are thankful to Director, ICARATARI, Bangalore and UAS, Raichur for funding and providing facility to conduct the experiment.

\section{References}

Chapke, R.R. (2012). Impact of Frontline Demonstrations on Jute (Corchorus olitorius). J. Human Eco, 38 (1): 37-41.

Dayanand, VRK. and Mehta, S.M (2012). Boosting mustard production through front line demonstrations. Indian Res. J. Ext Edu 12 (3): 121-123.

Katare, Subhash, Pandey, S.K. and Mustafa,
Mohd. (2011).Yield gap analysis of rapeseed mustard through front line demonstration. Agric. Update 6: 5-7.

Keshavareddy G., S. Kamala Bai, K. H. Nagaraj and Hanumantharaya B. G. (2018). Integrated Crop Management A Way for Doubling the Income of Tomato Growers in Ramanagara District of Karnataka, India. Int.J.Curr.Microbiol.App.Sci. $\quad$ 7(06): 2161-2168.

Mokidue, I., A. K. Mohanty and Sanjay, K. (2011). Correlating growth yield and adoption of Urdbean technology. Indian. J. Extn. Edu. 11(2): 20-24.

Singh., D.V., Mukhi, S.K. and Mohapatra, M.R. (2016). Yield Gap Analysis of Toria (Brassica campestris) through Front Line Demonstration in Kandhamal District of Odisha, Indian J. Ext. Edu, 52 (3\& 4), 167-17.

\section{How to cite this article:}

Kale, S.M., Barikar Umesh and Mahesh, C. 2020. Popularization of Tomato Hybrid (Arka Rakshak) for Yield and Economic Analysis in Kalyan Karnatka Region. Int.J.Curr.Microbiol.App.Sci. 9(06): 1675-1679. doi: https://doi.org/10.20546/ijcmas.2020.906.207 